\title{
Chemical Composition of the Main Pollen Collection by Honey Bee (Apis mellifera L.) at Kafr El-Sheikh Governorate \\ Fathy, H. M. ${ }^{1}$; L. A. El-Batran ${ }^{1}$; F. S. Serag El-Dien ${ }^{2}$ and Z. A. E. hassanein ${ }^{2}$ \\ ${ }^{1}$ Economic Entomology Dept., Fac. Agric., Mansoura Univ. \\ ${ }^{2}$ Bee Res. Dept., Agric Res. St., Sakha Kafr El-Sheikh
}

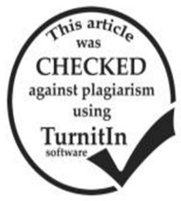

\section{ABSTRACT}

The current experiment aims to study chemical analysis of the main pollen collection according to different regions At Kafr El-Sheikh Governorate (Sidi Salem, Bialla and Kafr El-Sheikh). The results showed that in the three districts during 2014 season, the highest average of moisture content was found in pollen obtained from Vicia fabae with $28.93 \%, 29.00 \%$, and $29.00 \%$, respectively mean while, the least values of moisture was found in Eucalyptus spp. in Sidi Salem, Bialla and Kafr ElSheikh and represented by $27.70 \%, 28.50 \%$ and $26.90 \%$, respectively. The highest ash content $(4.44 \%)$ in Melilotus siculus in the three districts and the least average in Brassica Kabar (3.33\%), the highest average of fiber content was found in Salix safsaf $(2.31 \%)$ in the three districts and the least average was in Trifolium alexandrinum (1.27\%), the highest average of lipid found in Salix safsaf $(21.80 \%)$ and the least in Brassica kabar (20.73\%), the highest average of protein found in Trifolium alexandrinum $(32.17 \%)$ and the least average in Salix safsaf $(30.78 \%)$ and the highest average of carbohydrate content was found in pollen Brassica kabar (14.22\%) and the least average in Trifolium alexandrinum 12.67\%.

\section{INTRODUCTION}

Pollen is one of the vital important components to honey bee and also to bee keeper. It is the only source of nitrogenous food for bee larva, brood rearing and adult growth (Day et al., 1990). The absence of pollen surely leads to the extinction of the colony. Pollen is not only the main source of protein but also source of amino acids and provides vitamins, minerals and fats (Roulston et al., 2000) that are essential for the development of brood and young adult bees. Honeybee collected a large quantity of pollen from different crops over the year, but pollen gathering activity depends on some factors such as race of honey bee, honey bee health, environment conditions and planting area around the honey bee colonies (Serra et al., 1986).

The chemical composition of both trapped and stored pollen from various plant species was studied by several investigators. Pollen analysis helps to identify such honey. Walter (1980), in Argentina, estimated the chemical components of pollen as $22 \%$ protein, $26 \%$ reducing sugars, 3\% non-reducing sugars, 3\% starch, $11 \%$ water, as well as other substance. In addition, pollen has fats, vitamins (specially vit. B), carotene, oils and some hormones. Further, he found that pollen contain the essential amino acids in sufficient amounts for normal growth and development of honey bee. While, Hazem (2011) in Giza region found that the values of proximate chemical composition of palm pollen grains were moisture $(28.80 \%)$, ash $(4.57 \%)$, crude fiber $(1.37 \%)$, crude fat $(20.74 \%)$, crude protein (31.11\%) and carbohydrate (13.41\%).

\section{MATERIALS AND METHODS}

The present study was carried out in different regions in Kafr El-Sheikh Governorate (Kafr El-Sheikh, Sidi Salem and Bialla) for comparison between daily activity of pollen gathering in different regions during spring and summer season (2014). Fifteen colonies of first hybrid Carniolan honey bee (Apis mellifera L.). The experimental colonies were in equal strength and headed with sister recently mated queens. The colonies were divided into three equal groups (five colonies in every region) and these colonies were provided with pollen traps.
Estimation of monthly activity of pollen collection:

Pollen grains were collected from the traps monthly to know the monthly changes in amounts of trapped pollen during the period from March 2014 to February 2015.

Identification of collected pollen:

Separation of all pollen colors on their own, weekly weight and keep it in tubes in the freezer in the form of monthly collections and make slides of these colors, write the data on them to identify them via the electronic microscope and compared to the standard pollen catalog of different plants location in the region.

The collection pollen was classified through separation to different groups according to its color . seven samples (5 gm) of each pollen, The collected samples were subjected to chemical analysis and pollen types were carried out in laboratory of national research center, Cairo, Egypt to determine the following contents:

- Moisture content was determined by drying pollen sample to constant weight in an our oven at $60^{\circ} \mathrm{C}$, Then percentage of moisture content was estimated.

- Crude protein content was determined in duplicate According to Domas method (A.O.A.C., 2000).

- Lipid content of the pollen samples were measured gravimetrically after extraction with petroleum ether Through using a Soxhlet lipids extraction apparatus.

- Ash content was measured through heating pollen samples in a muffle furnace at $450^{\circ} \mathrm{C}$ until a uniform gray-white ash remained. The samples were then weighed for estimating the average percentage of the ash content (Bell et al, 1983)

- Fiber content was determined by following the standard procedures of A.O.A.C. (1995) and then representing percentage of fiber was estimated .

- The content of the carbohydrate and reducing sugar was determined according to the method reported by Gordon and Diane (2002).

\section{Statistical analysis :}

The obtained data were subjected to one way analysis of variance (ANOVA) and the differences among means of the treatments were separated using Duncans multiple range test, statistical analysis were done according to Mead et al. (1993). 


\section{RESULTS AND DISCUSSION}

Data in Table (1) present the moisture content percentage of pollen at the three tested districts during 2014 season.

The highest average of moisture content was found in pollen obtained from Vicia faba bean flowers, with $28.93 \%$, followed by maize and Brassica kabar, $28.30 \%$ moisture content each. On the other hand, the least values of moisture were detected in pollen of Eucalyptus (27.70\%) and Salix safsaf (27.77\%).

Table 1. Seasonal variation in moisture content percentages of pollen at different locations during 2014 season.

\begin{tabular}{lccc}
\hline Sources & Beiala & $\begin{array}{c}\text { Sidi } \\
\text { Salem }\end{array}$ & $\begin{array}{c}\text { Kafr El- } \\
\text { Sheikh }\end{array}$ \\
\hline $\begin{array}{l}\text { Melilotus siculus } \\
\text { Trifolium }\end{array}$ & $28.80 \mathrm{a}$ & $28.50 \mathrm{a}$ & $27.30 \mathrm{a}$ \\
alexandrinum & $29.00 \mathrm{a}$ & $28.35 \mathrm{a}$ & $27.20 \mathrm{a}$ \\
Zea mays & $27.30 \mathrm{a}$ & $29.10 \mathrm{a}$ & $28.50 \mathrm{a}$ \\
Vicia faba & $28.80 \mathrm{a}$ & $29.00 \mathrm{a}$ & $29.00 \mathrm{a}$ \\
Brassica kabar & $28.50 \mathrm{a}$ & $28.00 \mathrm{a}$ & $28.40 \mathrm{a}$ \\
Eucalyptus spp. & $28.50 \mathrm{a}$ & $27.70 \mathrm{a}$ & $26.90 \mathrm{a}$ \\
Salix safsaf & $27.50 \mathrm{a}$ & $27.30 \mathrm{a}$ & $28.50 \mathrm{a}$ \\
Average & $28.34 \mathrm{a}$ & $28.27 \mathrm{a}$ & $27.97 \mathrm{a}$ \\
\hline $\begin{array}{l}\text { Means followed the same letter in araw are not significant different at } \\
\text { the 5\% level of probability (Duncan"s multiple range test. }\end{array}$
\end{tabular}

Moisture contents of pollen, over the plant species, were almost the same at Beiala $(28.34 \%)$ and Sidi Salem (28.27\%), while the least value $(27.97 \%)$ was that at Kafr El-Sheikh

Data in Table (2) reveal the crude ash content percentage of pollen in three tested districts during seasons in 2014.

Table 2. Seasonal variation in ash content percentages of pollen in different locations:

\begin{tabular}{lccc}
\hline Sources & Beiala & $\begin{array}{c}\text { Sidi } \\
\text { Salem }\end{array}$ & $\begin{array}{c}\text { Kafr El- } \\
\text { Sheikh }\end{array}$ \\
\hline Melilotus siculus & $4.57 \mathrm{a}$ & $4.90 \mathrm{a}$ & $3.85 \mathrm{a}$ \\
Trifolium & $4.30 \mathrm{a}$ & $4.10 \mathrm{a}$ & $3.50 \mathrm{a}$ \\
alexandrinum & $4.60 \mathrm{a}$ & $2.90 \mathrm{a}$ & $3.75 \mathrm{a}$ \\
Zea mays & $4.65 \mathrm{a}$ & $3.70 \mathrm{a}$ & $4.10 \mathrm{a}$ \\
Vicia faba & $3.90 \mathrm{a}$ & $2.70 \mathrm{a}$ & $3.40 \mathrm{a}$ \\
Brassica kabar & $3.85 \mathrm{a}$ & $2.80 \mathrm{a}$ & $3.60 \mathrm{a}$ \\
Eucalyptus spp. & $4.31 \mathrm{a}$ & $3.50 \mathrm{a}$ & $3.60 \mathrm{a}$ \\
Salix safsaf & $4.31 \mathrm{a}$ & $3.51 \mathrm{a}$ & $3.68 \mathrm{a}$ \\
Average &
\end{tabular}

Means followed the same letter in araw are not significant different at the $5 \%$ level of probability (Duncan"s multiple range test.

Over the locations, the highest ash content $(4.44 \%)$ was recorded in Melilotus siculus pollen, followed by that in pollen of faba bean $(4.15 \%)$, clover $(3.97 \%)$ and Salix safsaf $(3.80 \%)$. Concerning the locations, Beiala came first (4.31\%), followed by Kafr El-Sheikh (3.68\%) and Sidi Salem (3.51\%).

It can be seen that all pollen samples of different plant sources contain amoderate amount of ash.The pollen pellets of maize and brood bean, relatively, countained the highest ash content. The trend of those general chemical analysis results are in aquite agreement with those obtained by Yossef (1978), Afify et al.,(1988) and Taha (2006) .
Over the locations (Table 3), pollen of Salix safsaf had the highest value $(2.31 \%)$ of fiber, followed by Eucalyptus $(2.20 \%)$ and faba bean (1.83). The least fiber value was recorded in pollen of clover $(1.27 \%)$ and maize $(1.48 \%)$. The other plant sources exhibited intermediate values of fiber in their pollen.

Over the plant sources, pollen of Sidi Salem contained the highest fiber $(1.86 \%)$ followed by almost the same value at Kafr El-Sheikh (1.84\%), while the least fiber was detected in pollen from Beiala (1.57\%).

Table 3. Seasonal variation in fiber content percentages of pollen in different locations:

\begin{tabular}{lccc}
\hline Sources & Beiala & $\begin{array}{c}\text { Sidi } \\
\text { Salem }\end{array}$ & $\begin{array}{c}\text { Kafr El- } \\
\text { Sheikh }\end{array}$ \\
\hline Melilotus siculus & $1.37 \mathrm{ab}$ & $2.15 \mathrm{ab}$ & $1.30 \mathrm{ab}$ \\
Trifolium & $1.30 \mathrm{~b}$ & $1.20 \mathrm{ab}$ & $1.30 \mathrm{~b}$ \\
alexandrinum & $1.10 \mathrm{~b}$ & $1.25 \mathrm{~b}$ & $2.10 \mathrm{ab}$ \\
Zea mays & $1.74 \mathrm{ab}$ & $2.25 \mathrm{~b}$ & $1.50 \mathrm{ab}$ \\
Vicia faba & $1.35 \mathrm{ab}$ & $1.35 \mathrm{ab}$ & $2.20 \mathrm{ab}$ \\
Brassica kabar & $2.00 \mathrm{a}$ & $1.90 \mathrm{a}$ & $2.70 \mathrm{ab}$ \\
Eucalyptus spp. & $2.19 \mathrm{a}$ & $2.95 \mathrm{a}$ & $1.80 \mathrm{a}$ \\
Salix safsaf & $1.57 \mathrm{a}$ & $1.86 \mathrm{a}$ & $1.84 \mathrm{a}$ \\
Average &
\end{tabular}

Means followed the same letter in araw are not significant different at the 5\% level of probability (Duncan"s multiple range test.

Data in Table (4) presented the crude lipid content percentages of pollen at three locations during season 2014. The highest lipid content $(21.80 \%)$ was found in pollen of Salix safsaf, followed by Eucalyptus $(21.78 \%)$ and clover $(21.75 \%)$, while the least values were recorded in pollen of Brassica kabar (20.73\%) and maize $(20.87 \%)$. Over the plant species, pollen gathered from Kafr El-Sheikh location had the highest lipid $(21.49 \%)$, followed by a very close value $(21.45 \%)$ at Sidi Salem, while pollen collected from Beiala location came least (21.11\%).

Table 4. Seasonal variation in lipid content percentages of pollen in different locations:

\begin{tabular}{lccc}
\hline Sources & Beiala & $\begin{array}{c}\text { Sidi } \\
\text { Salem }\end{array}$ & $\begin{array}{c}\text { Kafr El- } \\
\text { Sheikh }\end{array}$ \\
\hline Melilotus siculus & $20.74 \mathrm{a}$ & $21.90 \mathrm{a}$ & $21.90 \mathrm{a}$ \\
Trifolium & $21.00 \mathrm{a}$ & $21.75 \mathrm{a}$ & $22.50 \mathrm{a}$ \\
alexandrinum & $21.80 \mathrm{a}$ & $20.50 \mathrm{a}$ & $20.30 \mathrm{a}$ \\
Zea mays & $21.50 \mathrm{a}$ & $20.80 \mathrm{a}$ & $20.70 \mathrm{a}$ \\
Vicia faba & $20.40 \mathrm{a}$ & $21.20 \mathrm{a}$ & $20.60 \mathrm{a}$ \\
Brassica kabar & $20.74 \mathrm{a}$ & $21.80 \mathrm{a}$ & $22.80 \mathrm{a}$ \\
Eucalyptus spp. & $21.60 \mathrm{a}$ & $22.20 \mathrm{a}$ & $21.60 \mathrm{a}$ \\
Salix safsaf & $21.11 \mathrm{a}$ & $21.45 \mathrm{a}$ & $21.48 \mathrm{a}$ \\
Average &
\end{tabular}

Means followed the same letter in araw are not significant different at the 5\% level of probability (Duncan"s multiple range test.

Data in Table (5) revealed the crude protein content percentage of pollen during 2014/2015 at three locations. The highest crude protein 33\% was assessed in clover pollen at Sidi Salem. However, pollen grains of clover had usually the highest protein content $(32.17 \%)$, followed by pollen of Brassica kabar $(31.78 \%)$ and then, maize pollen $(31.57 \%)$. The least protein contents were detected in pollen of Eucalyptus $(30.92 \%)$ and Salix safsaf $(30.78 \%)$. As for locations, the pollen protein content were almost the same. 
Table 5. Seasonal variation in protein content percentages of pollen in different locations:

\begin{tabular}{lccc}
\hline Sources & Beiala & $\begin{array}{c}\text { Sidi } \\
\text { Salem }\end{array}$ & $\begin{array}{c}\text { Kafr El- } \\
\text { Sheikh }\end{array}$ \\
\hline Melilotus siculus & $31.11 \mathrm{ab}$ & $30.40 \mathrm{ab}$ & $32.10 \mathrm{ab}$ \\
Trifolium alexandrinum & $32.10 \mathrm{a}$ & $33.00 \mathrm{~b}$ & $31.40 \mathrm{a}$ \\
Zea mays & $32.00 \mathrm{ab}$ & $31.30 \mathrm{ab}$ & $32.00 \mathrm{ab}$ \\
Vicia faba & $31.11 \mathrm{ab}$ & $30.85 \mathrm{ab}$ & $31.60 \mathrm{ab}$ \\
Brassica kabar & $32.44 \mathrm{ab}$ & $31.50 \mathrm{~b}$ & $31.40 \mathrm{ab}$ \\
Eucalyptus spp. & $30.50 \mathrm{~b}$ & $31.35 \mathrm{~b}$ & $30.90 \mathrm{~b}$ \\
Salix safsaf & $30.90 \mathrm{ab}$ & $30.65 \mathrm{~b}$ & $30.80 \mathrm{~b}$ \\
Average & $31.45 \mathrm{ab}$ & $31.29 \mathrm{ab}$ & $31.45 \mathrm{ab}$ \\
\hline
\end{tabular}

Means followed the same letter in araw are not significant different at the 5\% level of probability (Duncan"s multiple range test.

Data in Table (6) revealed the crude carbohydrates content percentage of pollen during 2014 in three districts. The highest crude carbohydrate $14.70 \%$ was observed in Brassica kabar in Kafr El-Sheikh followed by Zea mays, Eucalyptus spp., and Salix safsaf (14.20, 13.90, 13.80\%), in Sidi Salem, the highest crude carbohydrate $14.55 \%$ in Brassica kabar followed by Zea mays, Eucalyptus and Salix safsaf $(14.10,13.65,13.30 \%)$ and in Beiala the highest crude carbohydrate $14.4 \%$ for Eucalyptus spp. Followed by Salix safsaf, Melilotus siculus and Brassica kabar (13.50, 13.41, $13.41 \%$ ). The lowest crude carbohydrate were observed in three district in Vicia faba $(12.20 \%, 13.00 \%, 13.50 \%)$.

Table 6. Seasonal variation in carbohydrate content percentages of pollen in different locations:

\begin{tabular}{lccc}
\hline Sources & Beiala & Sidi Salem & $\begin{array}{c}\text { Kafr El- } \\
\text { Sheikh }\end{array}$ \\
\hline Melilotus siculus & $13.41 \mathrm{bcd}$ & $13.20 \mathrm{ab}$ & $12.50 \mathrm{bcd}$ \\
Trifolium alexandrinum & $12.30 \mathrm{~d}$ & $12.20 \mathrm{~d}$ & $13.50 \mathrm{~cd}$ \\
Zea mays & $13.20 \mathrm{abc}$ & $14.10 \mathrm{abc}$ & $14.20 \mathrm{abc}$ \\
Vicia faba & $12.20 \mathrm{~cd}$ & $13.00 \mathrm{ab}$ & $13.50 \mathrm{~cd}$ \\
Brassica kabar & $13.41 \mathrm{a}$ & $14.55 \mathrm{a}$ & $14.70 \mathrm{a}$ \\
Eucalyptus spp. & $14.41 \mathrm{ab}$ & $13.65 \mathrm{ab}$ & $13.90 \mathrm{ab}$ \\
Salix safsaf & $13.50 \mathrm{abcd}$ & $13.30 \mathrm{abcd}$ & $13.80 \mathrm{abcd}$ \\
Average & $13.34 \mathrm{bcd}$ & $13.42 \mathrm{bcd}$ & $13.72 \mathrm{bcd}$ \\
\hline
\end{tabular}

Means followed the same letter in araw are not significant different at the 5\% level of probability (Duncan"s multiple range test.

Pollen collected from Brassica kabar flowers contained the highest carbohydrate content (14.22\%), followed by Eucalyptus (13.99\%) and maize (13.93\%). The least carbohydrate contents were assessed in faba bean and clover pollen grain; 12.90 and $12.67 \%$, respectively. Concerning the locations, pollens collected from Kafr ElSheikh plant flowers had the highest carbohydrate, with little differences between Kafr El-Sheikh and each of Sidi Salem and Beiala.These results are in agreement with Walter (1980), Almedia et al. (2005)

\section{REFERENCES}

A.O.A.C. (2000). Association of Official Analytical Chemists. Official Methods of Analysis. 17 $7^{\text {th }} \mathrm{Ed}$. A.O.A.C. International Washington DC, USA.

Afify, A .M ., Mohrous , T .S.; Al-Gendi ,S .H . and ElHemasy ,A .H. (1988): Chemical evaluation of lipid and Protein of four pollen pellets . J . Agric .sci . Mansoura univ., B (4):2030 -2040.

Almedia, L.B.; L.C. Pamplona; S.E. Coimbra and O.M. Bratha (2005). Chemical composition and botanical evaluation of dried bee pollen pellets. J. of Food Composition and Analysis, 18(3); 105-111.

Bell, R.R.; E.J. Thornber; J.L. Seet; M.T. Groves; P.H. Nerissa and D.T. Belb (1983). Composition and protein quality of honey bee collected pollen of Eucalyptus marginate and Eucalyptus calophylla. J. Nutrition, 113(12); 2479-2484.

Day, S.; R. Beyer; A. Mercer and S. Ogdon (1990). The nutrient composition of honey bee collected pollen in Otago. J. Apic Res., 29(3): 138-148.

Gordon, E.A. and M.B. Diane (2002). Determination of reducing sugars with 3-methyl-2-benzo - thiazolin onehydrazone. Department of Food Science and Technology, University of California, Davis, California 95616.

Hazem etal.,(2011). Brood and honey production of honeybee colonies requeened at various frequencies. Egypt. Apic. Res., 34(1): 9-14.

Mead, R.; R.N. Curnow and A.M. Harted (1993). Statistical Methods in Agriculture and Experimental Biology $92^{\text {nd }}$ Ed.). Chapman and Hall, London.

Roulston, T.H.; J.H. Cane and S.L. Buchmann (2000). What governs protein content of pollen: Pollinator preferences. Pollen Pistil Interaction, or Phylogeny? Ecological Monnographis, 70(4): 617-643.

Serra, B.; G.J. gonell and P.A. Gomez (1986). Pollen collected by honey bee in Spain. J. Vida Apicola, 19: 35-38.

Taha, A . A .(2006) : Comparative studies on some secondary products in different races .ph .D . thesis ,fac . Agric ., Mansoura univ ., 212 pag.

Walter, G. (1980). Bees, beekeeping, honey and pollination. AVI Publishing Company Inc.

Youssef ,A . M . (1978) : Chemical studies on pollen collected by honey bees in Giza region , Egypt . J .Apic . Res., 17 (3): 110- 113.

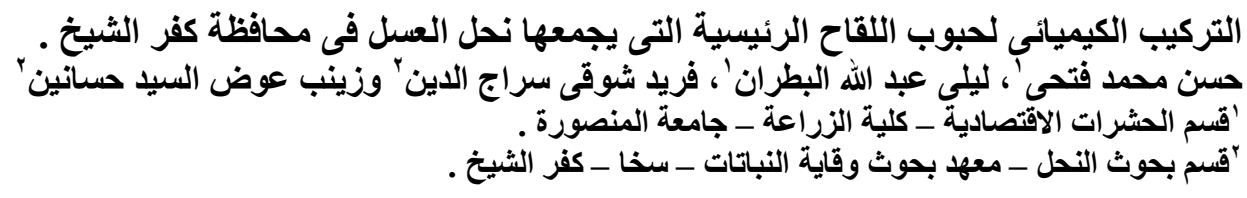

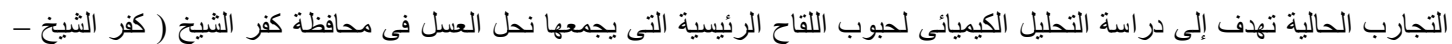

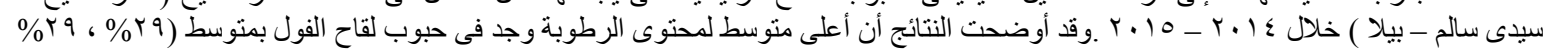

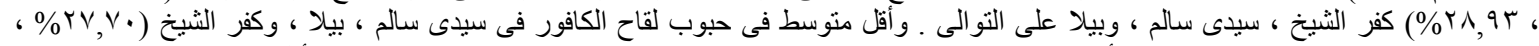

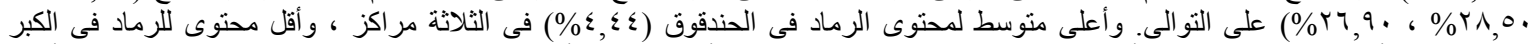

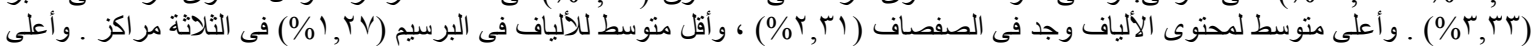

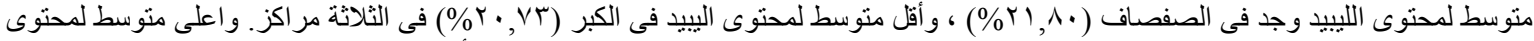

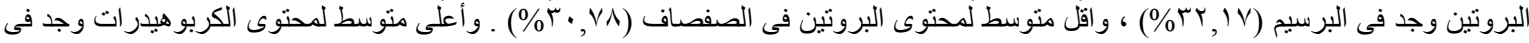

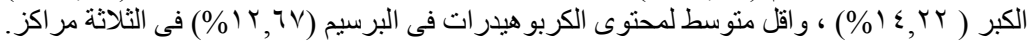

